\title{
Analisis Partisipasi Siswa Dalam Mengikuti Pembelajaran Bahasa Inggris di Masa Pandemi Covid-19 Di SDN Brawijaya
}

\author{
Restu Anastasia ${ }^{1}$, Arsyi Rizqia Amalia ${ }^{2}$, Din Azwar Uswatun ${ }^{3}$ \\ 1,2,3 PGSD/FKIP \\ Universitas Muhammadiyah Sukabumi \\ * Corresponding Author. E-mail: ${ }^{1}$ restuanas0808@ummi.ac.id, arsyrizqiaamalia@ummi.ac.id, \\ dinazwar@ummi.ac.id
}

\begin{abstract}
Abstrak
Penelitian ini memiliki tujuan yaitu untuk mendeskripsikan proses pembelajaran Bahasa Inggris dimasa pandemi dan partisipasi siswa. Jenis penelitian ini menggunakan metode deskriptif kualitatif, dan dilaksanakan dikelas II-B SDN Brawijaya Kota Sukabumi. Teknik pengumpulan data yang digunakan dalam penelitian ini yaitu wawancara dan observasi untuk mengetahui kegiatan proses pembelajaran, serta angket untuk mengetahui partisipasi siswa dalam mengikuti pembelajaran bahasa Inggris. Teknik analisis data pada penelitian ini menggunakan teknik analisis data model Miles dan Huberman yaitu reduksi data, penyajian data, dan penarikan kesimpulan. Hasil penelitian ini menunjukan bahwa pembelajaran bahasa Inggris dimasa pandemi dilakukan secara daring dengan menggunakan grup WhatsApp, dalam proses pembelajaran daring muncul empat partisipasi siswa.
\end{abstract}

Kata Kunci: Partisipasi Siswa; Pembelajaran Bahasa Inggris; Pandemi covid 19.

Abstract

This study has a purpose, namely to describe the learning process English during the pandemic and student participation. This type of research uses a qualitative descriptive method, and is carried out in class II-B SDN Brawijaya Sukabumi City. Data collection techniques used in this study were interviews and observations to determine the activities of the learning process, as well as a questionnaire to determine student participation in learning English. The data analysis technique in this study uses data analysis techniques using the Miles and Huberman model, namely data reduction, data presentation, and drawing conclusions. The results of this study indicate that learning English during the pandemic is carried out online using WhatsApp groups, in the online learning process four student participations appear

Keywords: Student Participation; English Learning; Covid-19 Pandemic.

\section{Pendahuluan}

Bahasa Inggris merupakan bahasa internasional penting yang dapat menghubungkan masyarakat dengan dunia dalam berbagai aspek termasuk aspek pendidikan. Mata pelajaran bahasa Inggris sebagai mata pelajaran wajib untuk dipelajari siswa dari sekolah dasar hingga jenjang level pendidikan tinggi. Pembelajaran bahasa Inggris diarahkan pada empat keterampilan di dalam bahasa Inggris antara lain: kemampuan mendengar (listening), berbicara (speaking), membaca (reading), dan kemampuan menulis (writing) Wijaya (2015:121). Bahasa Inggris perlu diajarkan sejak dini agar terbiasa kedepannya, hal ini sejalan dengan Fajaryani, N.dkk (dalam Faturohman \& Indihadi, 2016:60) yang mengatakan bahwa "mengajarkan bahasa Inggris sebagai bahasa asing khusunya kepada anak-anak yang berusia 5-12 tahun supaya mereka bisa mempelajari bahasa dengan baik". Pembelajaran bahasa Inggris juga dapat memanfaatkan media pendukung keterampilan berbahasa seperti mainan dan kegiatan menarik 
seperti gerak lagu dan sejenisnya yang ada sehingga akan semakin menarik dan bermakna, Fauzia et al (dalam Herdyastika \& Kuriawan, 2021:1586).

Peraturan Menteri Pendidikan Dan Kebudayaan Nomor 22 Tahun 2016 Tentang Standar Proses Pendidikan Dasar dan Menengah. Pelaksanaan pembelajaran merupakan implementasi dari RPP , meliputi kegiatan pendahuluan, inti dan penutup. Kegiatan pendahuluan dalam pelaksanaan pembelajaran dimana guru mulai menyiapkan peserta didik, membuka pelajaran, melakukan apersepsi, memotivasi siswa, dan menyampaikan tujuan pembelajaran. Selanjutnya yaitu kegiatan inti, di dalamnya guru harus menguasai materi pelajaran, menyampaikan materi dengan jelas, tidak lupa dengan penggunaan media, model , metode pembelajaran yang sesuai dengan materi yang diajarkan. Dalam kegiatan penutup guru melakukan refleksi untuk mengevaluasi diantaranya menyimpulkan pembelajaran, memberikan kesempatan peserta didik untuk bertanya, dan memberikan tugas untuk melakukan tindak lanjut. Guru tidak hanya menyampaikan pengetahuan, keterampilan, dan sikap kepada siswa, akan tetapi guru diharapkan mampu membawa siswa untuk aktif dalam berbagai aktivitas pembelajaran. Partisipasi siswa dalam proses pembelajaran dapat dilihat dari keaktifannya dalam mengikuti kegiatan proses belajar mengajar, perhatiannya terhadap guru saat menerangkan materi di kelas, dan mengutarakan.

Partisipasi dalam Kamus Besar Bahasa Indonesia (KBBI) mempunyai arti yaitu perihal turut berperan serta dalam suatu kegiatan, keikutsertaan, dan peran serta. Menurut Suryosubroto dalam (Sani \& Kurniasih, 2016:21) "partisipasi adalah keterlibatan mental dan emosi serta fisik anggota dalam memberikan inisiatif terhadap kegiatan-kegiatan yang dilancarkan oleh kelompok serta mendukung pencapaian tujuan dan bertanggungjawab atas keterlibatannya". Partisipasi siswa dalam mengikuti pembelajaran, siswa diharapkan mampu berpartisipasi secara aktif dalam kegiatan pembelajaran mulai dari awal pembelajaran hingga akhir secara optimal sehingga dapat tercapai tujuan pembelajaran.

Dengan adanya partisipasi belajar dari siswa, pembelajaran akan lebih terfokuskan untuk mendidik dan mengembangkan potensi dan aspek-aspek perkembangan siswa kearah yang lebih optimal. Siswa benar-benar diposisikan sebagai subyek yang sedang belajar, Handayani (2013:16).

Saat ini di dunia sedang marak-maraknya wabah Covid 19 atau biasa dikenal dengan virus corona, hal ini berdampak besar terhadap masyarakat salah satunya di bidang pendidikan. Hal ini menjadi problematika baru bagi guru dalam menyajikan materi pembelajaran agar siswa mencapai kompetensi yang diharapkan. Kompetensi siswa dapat tercapai dengan baik, apabila siswa dapat memberikan partisipasinya dalam proses pembelajaran secara aktif. Salah satu upaya pendidikan dalam melaksanakan kegiatan belajar mengajar dengan melakukan pembelajaran jarak jauh secara daring. Pembelajaran daring merupakan program penyelenggaraan kelas pembelajaran dalam jaringan untuk menjangkau kelompok target yang masif dan luas, Mandome \& Puasa (2020:186). Berbagai platform digital banyak digunakan pada saat proses pembelajaran berlangsung seperti classroom, google meet, zoom maupun melalui whatsapp grup. Penggunaan berbagai media yang digunakan dimasa pandemi dapat membantu dalam proses pembelajaran sesuai dengan tujuan yang ingin dicapai, Banyak hal faktor yang berasal dari internal maupun eksternal yang menyebabkan pembelajaran daring menjadi terhambat salah satunya adalah koneksi internet. Sama halnya yang dikemukakan oleh Gunawan et al (dalam Sudarsana, 2020:47) kendala yang paling sering muncul selama pelaksanaan pembelajaran online yaitu paket internet yang tidak dimiliki oleh peserta didik, keterbatasan akses internet, dan belum terbiasanya dengan pembelajaran online. Belum lagi faktor dari internal siswa itu sendiri dimana pada saat pandemi covid 19 siswa malas belajar. Dalam hal ini guru mempunyai peranan penting bagaimana caranya untuk memberikan pembelajaran yang dapat melibatkan siswa agar menjadi aktif.

Perkembangan belajar anak di rumah pada masa pandemi covid 19 ini akan cenderung berbeda dengan perkembangan belajar di sekolah sehingga guru harus memiliki berbagai inovasi, dan memberikan motivasi bagi siswa dalam melaksanakan KBM untuk meningkatkan partisipasi siswa secara aktif dalam proses kegiatan pembelajaran. Berdasarkan masalah 
Jurnal Edumaspul, 5 (2), Year 2021 - 530

(Restu Anastasia, Arsyi Rizqia Amalia, Din Azwar Uswatun)

tersebut peneliti ingin menganalisis bagaimana partisipasi siswa dalam mengikuti pembelajaran Bahasa Inggris dimasa pandemi covid-19.

\section{Metode}

Penelitian ini menggunakan metode kualitatif deskriptif dengan pendekatan studi kasus. Penelitian kualitatif adalah penelitian yang bermaksud untuk memahami fenomena tentang apa yang dialami oleh subjek penelitian secara holistik dan dengan cara deskripsi dalam bentuk kata-kata dan bahasa, pada suatu konteks khusus yang alamiah dan dengan memanfaatkan berbagai metode ilmiah, Moleong (2017:6). Penelitian dilakukan di SDN Brawijaya pada semester genap tahun ajaran 2020/2021, dari bulan Januari sampai dengan bulan Juni. Yang menjadi subjek penelitian adalah guru bahasa Inggris dan siswa kelas 2B yang berjumlah 20 siswa dengan (10 putra, 10 puteri), maka teknik pengambilan samplingnya adalah purposive sampling. Instrument yang digunakan adalah lembar observasi, pedoman wawancara, dan lembar angket. Teknik analisis data merujuk pada Miles and Huberman yaitu data reduction, data display, dan conclusion drawing.

\section{Hasil dan Pembahasan}

Berdasarkan hasil penelitian bahwa pelaksanaan pembelajaran bahasa Inggris khusunya untuk kelas bawah lebih banyak menggunakan media whatsapp, ketika menggunakan whatsapp banyak terbantu dalam pemberian tugas, pengiriman video, audio, dan voice note melalui whatsapp, selain fitur-fitur whatsapp juga menggunakan tambahan aplikasi google form dan youtube. Tambahan untuk siswa sumber belajar yang digunakan adalah buku paket dan LKS bahasa Inggris. Penggunaan whatsapp digunakan untuk mempermudah siswa dalam mengikuti proses pembelajaran, dan menjalin komunikasi antara guru dan siswa. Kendala pada saat proses pembelajaran yaitu masih ada siswa yang tidak memiliki fasilitas hp dan kuota hal tersebut menyebabkan pembelajaran menjadi terhambat, materi yang diberikan sangat tidak maksimal, tidak bisa memperbaiki contoh tugas menyebutkan angka. Kemudian kendala yang lain tidak banyak orang tua yang bisa membantu siswa dalam pelajaran bahasa Inggris.

Pembelajaran bahasa Inggris mengajarkan empat keterampilan yaitu listening, speaking, reading dan writing, keterampilan tersebut disampaikan kepada siswa akan tetapi keterampilan tersebut dibagi menjadi dua, diantaranya semester satu lebih memfokuskan pada keterampilan listening dan speaking untuk melatih pronounciation, lalu untuk di semester dua keterampilan tersebut di gabungkan dengan keterampilan reading dan writing.

Dalam proses pembelajaran guru bertanggung jawab dalam menyiapkan pembelajaran, mulai dari pemberian materi, hingga tugas-tugas yang dapat menambah pengetahuan siswa.

1. Kegiatan Pendahuluan Pembelajaran

Dalam proses pembelajaran dimulai dengan kegiatan pendahuluan, dimana guru memberikan kesan terbaik untuk menjadikan siswa ikut serta aktif pada proses pembelajaran dan dapat berlangsung dengan baik dari awal hingga akhir pembelajaran. Mulyasa (dalam Nurmanita 2018: 139) mengemukakan bahwa guru sangat berperan dalam memberikan motivasi kepada siswa, memberikan semangat, dan sebagai penyedia fasilitas seperti memberikan pelayanan kepada siswa yang membutuhkan pembelajaran. Guru membuka pelajaran diawali dengan mengucapkan salam, menyapa siswa dan memberikan motivasi dengan kata-kata dan emoticon yang ada di whatsapp, lalu menginformasikan materi apa yang akan dipelajari.

2. Kegiatan Inti Pembelajaran

Guru menyampaikan materi dalam bentuk file word yang dibagikan melalui grup whatsapp, dimana siswa menyalin materi kedalam buku tugas dan mengirimkan hasil tulisannya dengan cara difoto lalu dikirim ke grup whatsapp maupun secara japri. Menurut Elvandari (dalam Purbawati, 2020:105) tugas-tugas yang diberikan kepada siswa tidak dinilai seperti biasanya di sekolah, akan tetapi penilaian lebih banyak kualitatif yang sifatnya memberi motivasi kepada siswa dan hasil belajar diperoleh melalui pengamatan terhadap sikap siswa selama berlangsungnya proses pembelajaran. Guru mengadakan penilaian proses dan hasil belajar siswa dengan melakukan test ulangan harian menggunakan google form, sebelum tes 
dimulai guru memberikan arahan bagaimana cara menggunakan google form, dimana soal terdiri dari 10 pertanyaan, jika nilai masih dibawah 80 siswa diharuskan mengulang tes, pengerjaan tes ini dibatasi hingga pukul 20:00 malam.

\section{Kegiatan Penutup Pembelajaran}

Menurut Emda (2017:173) tercapainya tujuan pembelajaran merupakan salah satu faktor yang sangat menentukan keberhasilan belajar mengajar. Pendapat tersebut sesuai dengan hasil pengamatan bahwa kegiatan penutup guru memberikan tugas kepada siswa sekaligus selama tiga minggu kedepan, dengan pemberian tugas siswa dapat berlatih dan guru dapat mengetahui tingkat pemahaman siswa dalam materi bahasa Inggris. Keberhasilan belajar tidak hanya dilihat dari tugas yang dikerjakan siswa, akan tetapi motivasi ikut andil dalam tercapainya tujuan pembelajaran, seperti halnya motivasi yang diberikan oleh guru. Hal tersebut selaras dengan pendapat menurut Masni 2015 (20:38) motivasi merupakan dorongan dasar yang menggerakkan seseorang dalam bertingkah laku dalam mencapai suatu tujuan. Hal tersebut sesuai dengan hasil penelitian bahwa guru menutup pembelajaran dengan memberikan apresiasi kepada peserta didik yang sudah mengerjakan dan mengumpulkan tugas tepat waktu di minggu sebelumnya dan memberikan kata-kata yang memotivasi siswa.

Dalam pembelajaran siswa harus ikut serta aktif dalam proses pembelajaran, mulai dari mengikuti pembelajaran dari awal hingga akhir, memperhatikan guru, hingga mengerjakan soal, hal ini selaras dengan pendapat menurut Cahya (2015:50). "partisipasi siswa dalam belajar dapat ditunjukkan dengan keaktifannya dalam proses belajar mengajar, menjadi pertanyaan dalam pikirannya, serta dapat berkomunikasi timbal balik dalam pembelajaran". Pendapat lain yang dikemukakan oleh Rusman (dalam Rahayu 2014:22) bahwa pembelajaran partisipatif yaitu pembelajaran yang melibatkan siswa dalam kegiatan pembelajaran secara optimal.

Pembelajaran daring bahasa Inggris dimasa pandemi masuk dalam kategori cukup, pada saat pembelajaran ketika guru membuka pembelajaran siswa langsung merespon guru dan siap mengikuti pembelajaran bahasa Inggris secara daring. Partisipasi siswa dalam bertanya pada pembelajaran bahasa Inggris masuk kedalam kategori kurang, hal tersebut terlihat dari hasil observasi pada saat proses pembelajaran daring peneliti tidak melihat adanya siswa mengajukan pertanyaan mengenai materi pembelajaran yang diberikan oleh guru, guru tidak memberikan kesempatan siswa untuk bertanya. Partisipasi siswa sebenarnya dapat dilihat dari berbagai hal, seperti bagaimana frekuensi dari kegiatan bertanya siswa di dalam kelas Ekawati (dalam Ikasari \& Juliangkary 2015:133). Menurut Jannah (2020:90) partisipasi siswa bisa rendah dalam pembelajaran dapat diakibatkan oleh beberapa faktor, diantaranya adalah kurangnya kemampuan merumuskan gagasan yang dimiliki siswa, kurangnya keberanian menyampaikan pendapat, dan belum terbiasa bersaing dengan teman lainnya. Secara garis besar partisipasi siswa dalam bertanya tergolong kurang yang mengakibatkan pembelajaran belum maksimal dan interaksi dalam pembelajaran kurang karena tidak ada komunikasi antara guru dan siswa dalam pembelajaran bahasa Inggris dimasa pandemi.

Partisipasi siswa dalam menjawab masuk kedalam kategori cukup, terlihat dari hasil observasi pada saat proses pembelajaran sedang berlangsung pada saat guru membuka pembelajaran siswa menjawab salam, akan tetapi respon siswa dalam menjawab pertanyaan guru berkaitan materi tidak ada, guru tidak terlihat mengajukan pertanyaan berkaitan materi pembelajaran kepada siswa. Silvia (2014:4) untuk mendorong partisipasi dapat dilakukan dengan berbagai cara, antara lain memberikan pertanyaan dan menanganggapi respon siswa secara positif.

Partisipasi siswa dalam mengerjakan soal test masuk kedalam kategori kurang, Arifin (dalam Suherman, 2018:133) tes dalam kegiatan belajar mengajar merupakan suatu cara untuk mengevaluasi suatu kegiatan didalamnya ada bagian yang harus dikerjakan oleh siswa, kemudian hasil pekerjaan siswa tersebut diterjemahkan sebagai keberhasilan dari pencapaian siswa tersebut. pendapat tersebut berkaitan dengan hasil penelitian yang dilakukan guru memberikan soal tes yang dilakukan melalui google form, pemberian soal ulangan harian dilakukan untuk mengetahui sejauh mana pemahaman siswa terhadap materi yang sudah dipelajari selama proses pembelajaran secara daring. 
Partisipasi siswa dalam menyelesaikan tugas rumah termasuk dalam kategori cukup, ketika proses pembelajaran sedang berlangsung di grup whatsapp terlihat siswa mengerjakan tugas yang diberikan guru dengan baik, siswa mengirimkan tugas sesuai dengan arahan guru dengan cara mengirimkan melalui grup whatsapp maupun melalui japri langsung kepada guru yang bersangkutan, Menurut Prihatini (dalam Rudini \& Agustina, ,2021:772) pemberian pekerjaan rumah merupakan metode mengajar yang diberikan guru kepada siswanya dengan tujuan membiasakan dan merangsang siswa tekun, rajin, ulet dan giat belajar terutama belajar di rumah. Bentuk tugas yang dikerjakan siswa berupa hasil tulisan siswa dan audio untuk melatih siswa dalam hal menulis (writing), membaca (reading) dan berbicara (speaking). Selain pengumpulan tugas secara daring siswa mengumpulkan tugas ke sekolah dengan mengumpulkan hasil pengerjaan tugas yang ada di LKS dan buku paket.

Dari penjabaran perindikator partisipasi siswa dapat disimpulkan bahwa partisipasi siswa dalam mengikuti pembelajaran bahasa Inggris dimasa pandemi covid 19 berdasarkan hasil jumlah rata-rata angket seluruh indikator mendapat skor 4,8 yang termasuk kedalam kategori kurang. Hal tersebut yang menjadikan proses pembelajaran bahasa Inggris secara daring belum maksimal dimasa pandemi covid 19 yang berbantuan media whatsapp grup saja, guru belum memanfaatkan media tatap maya sehingga kurang nya komunikasi antara guru dan siswa yang menyebabkan partisipasi siswa masih belum optimal, dan tujuan pembelajaranpun kurang tersampaikan secara baik kepada siswa.

Tabel 1. Hasil angket partisipasi siswa

\begin{tabular}{|c|c|c|c|}
\hline Aspek & No Butir & $\begin{array}{c}\text { Rata- } \\
\text { rata }\end{array}$ & Kategori \\
\hline $\begin{array}{c}\text { Pembelajaran } \\
\text { daring bahasa } \\
\text { Inggris }\end{array}$ & $\begin{array}{c}1,2,3,4, \\
5, \text { dan } 6\end{array}$ & 5,18 & Cukup \\
\hline $\begin{array}{c}\text { Partisipsi } \\
\text { siswa dalam } \\
\text { bertanya }\end{array}$ & 7 dan 8 & 4,3 & Kurang \\
\hline $\begin{array}{c}\text { Partisipasi } \\
\text { siswa dalam } \\
\text { menjawab }\end{array}$ & 9 dan 10 & 5,15 & Cukup \\
\hline $\begin{array}{c}\text { Partisipasi } \\
\text { siswa dalam } \\
\text { mengerjakan } \\
\text { soal test }\end{array}$ & 11 dan \\
12 & 4,15 & Kurang \\
\hline $\begin{array}{c}\text { Partisipasi } \\
\text { siswa dalam } \\
\text { menyelesaikan } \\
\text { tugas rumah }\end{array}$ & $\begin{array}{c}14,15, \\
\text { dan } 16\end{array}$ & 5,025 & Cukup \\
\hline \multicolumn{2}{|l|}{ Jumlah Rata-rata } & $\mathbf{4 , 8}$ & Kurang \\
\hline
\end{tabular}

\section{Simpulan}

Berdasarkan hasil penelitian, dapat disimpulkan bahwa proses pembelajaran bahasa Inggris dimasa pandemi covid-19 menggunakan sistem daring dengan berbantuan aplikasi Whatsapp sebagai media pembelajarannya yang menghubungkan antara guru dan siswa. Partisipasi siswa dalam mengikuti pembelajaran bahasa Inggris di masa pandemi covid 19 yang diteliti dan dianalisis ada empat partisipasi siswa yang muncul diantaranya partisipasi siswa dalam bertanya, partisipasi siswa dalam menjawab, partisipasi siswa dalam mengerjakan soal tes, dan partisipasi siswa dalam menyelesaikan tugas rumah. Partisipasi siswa dalam bertanya pada saat proses pembelajaran berlangsung tidak ada pertanyaan yang diajukan siswa kepada guru seperti bertanya mengenai materi pembelajaran. Partisipasi siswa dalam menjawab ketika 
proses pembelajaran bahasa Inggris berlangsung selalu menjawab pertanyaan-pertanyaan dari guru dimulai dari awal pembelajaran hingga penutup. Partisipasi siswa dalam mengerjakan soal test ketika siswa mengerjakan soal test secara daring melalui google form siswa mengerjakan dengan baik sesuai kemampuan siswa. Partisipasi siswa dalam menyelesaikan tugas rumah siswa mengerjakan tugas yang diberikan oleh guru secara mandiri dan sesuai kemampuan siswa, dan dalam pengumpulan tugas sebagian besar siswa mengumpulkan nya tepat waktu.

\section{Daftar Pustaka}

Cahya, S. B. (2015). Pengaruh Disiplin Dan Partisipasi Siswa Terhadap Prestasi Belajar Melaksanakan Komunikasi Bisnis Siswa Smk Di Kecamatan Dawarblandong Dengan Percaya Diri Sebagai Variabel Moderasi. Jurnal Ekonomi Pendidikan Dan Kewirausahaan, 3(1), 50. https://doi.org/10.26740/jepk.v3n1.p48-60

Emda, A. (2017). Kedudukan Motivasi Belajar Siswa dalam Pembelajaran. Lantanida Journal, 5(2), 174-182.

Faturohman, I., Yasbiati, \& Indihadi, D. (2016). Pengaruh Penggunaan Media The Thing Puzzle Terhadap Kemampuan Siswa Menulis Kalimat Deskripsi Pada Pembelajaran Bahasa Inggris Di Kelas V. 57-64.

Handayani. (2013). Meningkatkan Partisipasi Belajar Siswa Dalam Pembelajaran IPS Menggunakan Metode Role Playing Pada Siswa Kelas V SD Negeri Playen III (Issue September). Universitas Negeri Yogyakarta.

Herdyastika, M., \& Kuriawan, M. (2021). Analisis Perbandingan Implementasi Metode Pembelajaran Bahasa Inggris Inovatif di Taman Kanak-Kanak. Jurnal Obsesi: Jurnal Pendidikan Anak Usia Dini, 5(2), 1585-1593.

Ikasari, J., Nissa, I. C., \& Juliangkary, E. (2017). Identifikasi Bentuk Partisipasi Siswa Smp Dalam Pembelajaran Matematika Berbasis Elpsa. Media Pendidikan Matematika, 5(2), 131145.https://doi.org/10.33394/mpm.v5i2.1794

Jannah, F. N., Setyawan, A., \& Citrawati, T. (2020). Identifikasi Partisipasi Siswa Kelas IV SD Negeri Junganyar 2 dalam Pembelajaran Matematika. Prosiding Nasional Pendidikan: LPPM IKIP PGRI Bojonegoro, 1(1), 90-94.

Mandome, A., \& Puasa, A. T. (2020). Efektifitas Implementasi Pembelajaran Daring Google Classroom Pada Mahasiswa Ilmu Komunikasi Universitas Sariputra Indonesia Tomohon. Komunikologi: Jurnal Pengembangan Ilmu Komunikasi Dan Sosial, 4(2), 184-195. https://doi.org/10.30829/komunikologi.v4i2.8400

Masni, H. (2015). Strategi Meningkatkan Motivasi Belajar Mahasiswa. Dikdaya, 05(01), 34-45.

Moleong, L.J (2017). Metodologi Penelitian Kualitatif. Cetakan ke 36. Bandung. PT Remaja Rosdakarya.

Nurmanita, M. (2018). Peranan Guru PPKN Dalam Membentuk Sikap Partisipatif Siswa di Sekolah Menengah Atas. 8(1), 137-147.

Purbawati, C., Rahmawat, L. E., Hidayah, L. N., \& Wardani, L. S. P. (2020). Tingkat Partisipasi Siswa Sekolah Menengah Pertama Dalam Pembelajaran Daring Di Masa Pandemi Covid-19. Jurnal Ilmiah Kependidikan, 11(103-108).

Rahayu, E. D. (2014). Partisipasi dan Hasil Belajar Siswa Melalui Kombinasi Strategi Pembelajaran 
Jurnal Edumaspul, 5 (2), Year 2021 - 534

(Restu Anastasia, Arsyi Rizqia Amalia, Din Azwar Uswatun)

Peningkatan Kemampuan Berfikir dengan Game Jcross Pada Mapel IPS Kelas VIII di SMPN 1 Winong Pati Tahun Pelajaran 2013/2014. Universitas Negeri Semarang.

Rudini, M., \& Agustina, A. (2021). Analisis Motivasi Siswa dalam Mengerjakan Tugas Rumah Di SMA Al- Mannan Tolitoli. Jurnal Cendekia: Jurnal Pendidikan Matematika, 05(01), 770-780.

Sani, A., Lestari, A., \& Kurniasih, N. (2016). Peningkatan Kemampuan Representasi Matematis Dan Partisipasi Siswa Melalui Penerapan Model Pembelajaran Artikulasi. 19-24.

Silvia, N., Yusrizal, \& Hendrizal. (2014). Peningkatan Partisipasi Pembelajaran Siswa Kelas V Dengan Model Problem Based Learning Di SDN 09 Pauh Barat Kota Pariaman. Jurnal Fakultas Keguruan Dan Ilmu Pendidikan, 2(1), 1-12.

Sudarsana.et al., (2020). COVID-19: Perspektif Pendidikan (K. A. P. Dewi \& J. Simarmata (eds.); Cetakan 1). Yayasan Kita Menulis.

Suherman, I. (2018). Pengelolaan Program Ulangan Harian Bersama ( UHB ) Sebagai Upaya Meningkatkan Motivasi Belajar Siswa. 2(2), 132-143.

Wijaya, I. K. (2015). Pembelajaran Bahasa Inggris Di Sekolah Dasar. Bahtera : Jurnal Pendidikan Bahasa Dan Sastra, 14(2), 120-128. 